\title{
Role of Mother and Social Maturity among Children in Poverty Setting
}

\author{
Anupa Sharma ${ }^{1}$, Sabiya Asmat ${ }^{2 *}$ and Tashi Dolkar ${ }^{2}$ \\ ${ }^{1}$ Department of Social Welfare, Jammu, Jammu \& Kashmir, India \\ ${ }^{2}$ Krishi Vigyan Kendra, Kargil I\& II, S. K University of Agriculture Science \& Technology of \\ Kashmir, Jammu and Kashmir, India \\ *Corresponding author
}

\section{A B S T R A C T}

Social maturity makes an individual skilled and competent to be a civilized member of society. It means knowing what to do and striving for it by following role models to reach

Keywords

Parenting, Mothers,

Women, Slum

setting, Social

competence, Social

maturity,

Encouragement of

social maturity,

Preschool children, ICDS and Jammu

Article Info

Accepted:

04 July 2019

Available Online:

10 August 2019 the desired level of acceptable social behaviour. Although there are numerous agents play their respective parts in development of social maturity. Mothers are considered to be important in encouraging the child on different aspects as mothers are considered to be the first whom the child feels, observes and learns with. The focus of the present paper is on the study of gender and age differences in encouragement of social maturity among children in poverty setting in slums of Jammu city. The sample comprised 400 children in the age of 3-6 years which were further divided into two groups i.e. 200 Anganwadi children (attending preschool component of ICDS) and 200 Home Based children (not going to ICDS centres or availing any preschool programme). Encouragement of social maturity provided to children by mothers was studied by using modified stimulation scale primarily based on Mohite Home Inventory (MHI). The study employed quantitative research design. The data obtained was analysed by using mean scores, standard deviation and t-test for this component. The results revealed the difference on encouragement of social maturity among children 4-5 years and 5-6 years of age where HBG received more encouragement from their mothers in respect of asking to do household work, cooperation and pro-social qualities. Age trend on this indicator also showed significant difference on all the aspects of encouragement of social maturity except promoting prosocial qualities in AWG and asking child to take care of siblings among HBG.

\section{Introduction}

Young children develop social and emotional competence through interaction, sharing, helping and cooperation with others in the two major contexts in which they spend time i.e. home and preschool. Social maturity is the condition of possessing the social, emotional and intellectual skills and behaviour needed to succeed as a member of the society (www.children healthencyclopedia.com). It can be said that mother and teacher play vital role in the development of child. As Jemni (1963), the writer of 'Brahamputra' says, "The child learns the best lesson of citizenship between the kiss of the mother and the care of the father" (Manocha and Balda, 2011). The pivotal role of being a mother is still the 
divine mission assigned to women alone. From a classic poem written by Willliam Rose Wallace entitled "What Rules the World", he said that the hand that rocks the cradle is the hand that rules the world. It illustrates the influence a mother plays to her child and in the long run to the society; that as a mother strives to nurture and teach a child, she explicitly makes the world a much better place indeed she is from low socio economic strata too. The way in which the parents communicate with the child, the choice of words, the underlying ideas and values, the extent to which they give meaning to their experiences have a lasting impact in shaping the personality of the child. Lack of stimulation and an unresponsive environment can hamper children's overall development. In day to day life, mothers perform certain activities consciously or unconsciously which may become an effective simulative channel for the development of children.

Even though most parents want to encourage their children's development, many do not know when to provide the proper experiences (Manocha, 2010). These aspects of the parents as a teacher include knowledge of normal child development and the ability to 'read' children's readiness for given experiences. Parents and other adults can influence a young child's social development directly as "social managers." This means actively giving children opportunities to interact with others and often guiding their interactions as appropriate. In this manner, parents and caregivers directly manage a child's social interactions or opportunities to teach skills and assist in building relationships (Brotherson, 2006).

Children in poverty setting suffer more as their parents are unaware of importance of social development and their less involvement with children. Pooja (1997) observed that low stimulation was provided by the mothers of slum children for their development. The low level of maternal involvement is due to lack of resources and more manual labour, when mothers go out to work, either the older sibling looks after the younger ones or they have to manage at their own thus getting early social maturity (Manocha and Balda, 2011). Parent education should emphasize interpreting child behaviour as it relates to the timing of experiences, especially for parents who may feel that infants and toddlers cannot benefit from early stimulation. Parents also need to know 'what to' provide in the way of stimulation and 'how to' do so. This might involve, at earlier ages, give and take, social games, whereas later in the development, mutual activities such as cooking, storytelling, and play could be the vehicles for parental involvement and helps the child in encouraging the social competence. With this background, following objectives were undertaken for the present research:

To determine the extent of maternal stimulation provided to preschool children in selected poverty setting for development of social maturity.

To study the difference on encouragement of social maturity provided to anganwadi and home based children at homes.

\section{Materials and Methods}

The universe for the present study was urban slum children of Jammu district. From this, two sub-groups of slum children were selected as sample group. Multistage sampling at the level of slum areas, Anganwadi centres and Anganwadi children was done to obtain the desired sample as per the procedure mentioned below. There are total 11 blocks in Jammu district out of which only two blocks are in urban areas (Gandhi Nagar and Jammu block) and have slum population. Both these urban blocks were selected. The list of slum areas 
present in these blocks was prepared with the help of data from Social Welfare Department. The slum areas were selected randomly using lottery method. A list of Anganwadi Centres in each selected slum area was prepared and 10 Anganwadis were selected randomly through lottery method. The Core group for the study consisted of 200 mothers of children who were in the age range 3-6 years and were attending the selected Anganwadi centres which means not only the enrolled children in ICDS centres but also visiting and regularly attending the Anganwadi centres for preschool educational activities. This group was referred as the Anganwadi (AW) group. Group $2^{\text {nd }}$ comprised 200 mothers of children between 36 years of age who were not attending Anganwadi or any other preschool centre. It was referred as the Home based (HB) group. Both the groups were selected from the similar socio-economic settings (i.e. urban slum area of Jammu district).

Socio-Economic Status (SES) Scale was used for matching the anganwadi and home based children. Stimulation Scale A modified Stimulation Scale was developed to study the encouragement of social maturity for the age group 3-6 years using relevant items from other standardized tools mainly Mohite Home Environment Inventory; 1989, (JHES) Jaswal Home Environment Scale;1998 and Tamil Naidu Children Environment Rating Scale (TECERS);2001. The statements were finalized with the help of experts in the field of child development.

\section{Results and Discussion}

\section{Sample Profile}

In the present study, an equal number of $\mathrm{HB}$ and AW children were selected for inclusion in the sample. The distribution of the sample in Table 1 shows that there were more females $(57 \%)$ than males $(43 \%)$ in the sample.
Encouragement of Social Maturity (3-4 years)

Table 2 reveals the stimulation provided by mothers to young children (3-4 years) for development of social maturity. The data revealed that the females among AWG were asked to take care of siblings more than the male children $(\mathrm{t}=4.56)$. During eating times family members were reported to be with female children $(t=2.71)$. Children belonging to HBG (0.85) were asked by mothers to perform household work more than the AW group (0.76) (Perhaps since they remained at home more time), though the difference was not significant. Overall, encouragement of social maturity was found to be significantly different in four aspects (taking care of siblings, presence of family members during eating times, greeting the child and promoting prosocial behaviour) for $\mathrm{AW}$ and $\mathrm{HB}$ groups for this age group but significant gender difference were observed in both the groups with overall $\mathrm{t}$-score more than the table value i.e. 1.88 and 3.14 respectively.

\section{Encouragement of Social Maturity (4-5} years)

As seen in table 3, In terms of asking children to do household work, it was seen that in both the groups (AWG and $\mathrm{HBG}$ ), gender differences existed since more of females were asked to take up this responsibility. The difference in this regard was significant in HBG. For taking care of siblings too, more of females than males were given this responsibility and the difference (male and female) in this regards were found to be significant. Females in both the AWG and HBG were given more of these jobs by the mother. With respect to another category, it was seen that in AWG, mothers/family members were seen with male children than female children at the time of meals. There was no difference in this regard among HBG. 
Int.J.Curr.Microbiol.App.Sci (2019) 8(8): 155-161

Table.1 Distribution of Sample According to age and gender

\begin{tabular}{|c|c|c|c|c|c|c|}
\hline \multirow{2}{*}{$\begin{array}{l}A G E \\
\text { (in } \\
\text { years) }\end{array}$} & \multicolumn{2}{|c|}{ HBG $(n=200)$} & \multicolumn{2}{|c|}{ AWG $(n=200)$} & \multicolumn{2}{|c|}{ Total $(n=400)$} \\
\hline & $M$ & $F$ & $M$ & $F$ & $M$ & $F$ \\
\hline $3-4$ & $43(21.5)$ & $83(41.5)$ & $53(27)$ & $56(28)$ & $97(24.25)$ & $139(34.75)$ \\
\hline $4-5$ & $11(5.5)$ & $36(18)$ & $35(17.5)$ & $8(4)$ & $46(11.5)$ & $44(11)$ \\
\hline \multirow{2}{*}{$\begin{array}{c}5-6 \\
\text { Total }\end{array}$} & $3(1.5)$ & $24(12)$ & $25(12.5)$ & $22(11)$ & $28(7)$ & $46(11.5)$ \\
\hline & $57(28 \%)$ & $\begin{array}{c}143 \\
(72 \%)\end{array}$ & $\begin{array}{c}114 \\
(57 \%)\end{array}$ & $86(43 \%)$ & $171(43 \%)$ & $229(57 \%)$ \\
\hline
\end{tabular}

Table.2 Mean Score Distribution on Encouragement of Social Maturity of Sample Children (3-4 years)

\begin{tabular}{|c|c|c|c|c|c|c|c|c|c|}
\hline \multirow[t]{2}{*}{ Indicators } & \multicolumn{4}{|c|}{ AWG $(n=200)$} & \multicolumn{4}{|c|}{ HBG $(n=200)$} & \multirow{2}{*}{$\begin{array}{c}\begin{array}{c}\text { Overall } \\
\text { t-value } \\
(3 \& 6)\end{array} \\
\text { AWG\&HBG }\end{array}$} \\
\hline & $\begin{array}{c}\text { Male(1) } \\
(n=54)\end{array}$ & $\begin{array}{c}\text { Female(2) } \\
(n=56)\end{array}$ & $\begin{array}{l}\text { Total(3) } \\
(n=110)\end{array}$ & $\begin{array}{l}\text { t(1\&2) } \\
\text { AWC } \\
(M-F)\end{array}$ & $\begin{array}{c}\text { Male(4) } \\
(n=43)\end{array}$ & $\begin{array}{c}\text { Female }(5) \\
\quad(n=83)\end{array}$ & $\begin{array}{l}\text { Total(6) } \\
(n=126)\end{array}$ & $\begin{array}{c}\mathrm{t}(\mathbf{4 \& 5}) \\
\mathrm{HB} \\
(\mathrm{M}-\mathrm{F})\end{array}$ & \\
\hline $\begin{array}{l}\text { Mother asks } \\
\text { child to do } \\
\text { house work }\end{array}$ & $\begin{array}{c}0.73 \\
\pm 0.44 \\
0.055\end{array}$ & $\begin{array}{c}0.79 \\
\pm 0.40 \\
0.05\end{array}$ & $\begin{array}{c}0.76 \\
\pm 0.42 \\
0.04\end{array}$ & 0.78 & $\begin{array}{c}0.77 \\
\pm 0.25 \\
0.03\end{array}$ & $\begin{array}{c}0.93 \\
\pm 0.42 \\
0.04\end{array}$ & $\begin{array}{c}0.85 \\
\pm 0.38 \\
0.03\end{array}$ & $2.25^{*}$ & 1.17 \\
\hline $\begin{array}{l}\text { Mother asks } \\
\text { child to take } \\
\text { care of siblings }\end{array}$ & $\begin{array}{c}0.33 \\
\pm 0.24 \\
0.06\end{array}$ & $\begin{array}{c}0.74 \\
\pm 0.47 \\
0.06\end{array}$ & $\begin{array}{c}0.53 \\
\pm 0.40 \\
0.04\end{array}$ & $4.56^{*}$ & $\begin{array}{c}0.36 \\
\pm 0.28 \\
0.07\end{array}$ & $\begin{array}{c}0.37 \\
\pm 0.28 \\
0.05\end{array}$ & $\begin{array}{c}0.36 \\
\pm 0.26 \\
0.04\end{array}$ & 0.11 & $2.67 *$ \\
\hline $\begin{array}{l}\text { During eating } \\
\text { times family } \\
\text { members are } \\
\text { with child }\end{array}$ & $\begin{array}{c}0.29 \\
\pm 0.16 \\
0.06\end{array}$ & $\begin{array}{c}0.55 \\
\pm 0.50 \\
0.06\end{array}$ & $\begin{array}{c}0.42 \\
\pm 0.29 \\
0.04\end{array}$ & $2.71 *$ & $\begin{array}{c}0.79 \\
\pm 0.41 \\
0.06\end{array}$ & $\begin{array}{c}0.34 \\
\pm 0.27 \\
0.52\end{array}$ & $\begin{array}{c}0.56 \\
\pm 0.30 \\
0.04\end{array}$ & $5.30 *$ & $2.99 *$ \\
\hline $\begin{array}{l}\text { Mother greets } \\
\text { the child }\end{array}$ & $\begin{array}{c}0.58 \\
\pm 0.49 \\
0.06\end{array}$ & $\begin{array}{l}0.40 \\
\pm 0.9 \\
0.06\end{array}$ & $\begin{array}{c}0.49 \\
\pm 0.20 \\
0.04\end{array}$ & 1.9 & $\begin{array}{c}0.39 \\
\pm 0.04 \\
0.05\end{array}$ & $\begin{array}{c}0.12 \\
\pm 0.09 \\
0.04\end{array}$ & $\begin{array}{c}0.25 \\
\pm 0.15 \\
0.04\end{array}$ & $3.25^{*}$ & $3.30 *$ \\
\hline $\begin{array}{c}\text { Mother } \\
\text { promotes } \\
\text { cooperation, } \\
\text { sharing and } \\
\text { helping }\end{array}$ & $\begin{array}{c}0.77 \\
\pm 0.41 \\
0.05\end{array}$ & $\begin{array}{c}0.71 \\
\pm 0.45 \\
0.06\end{array}$ & $\begin{array}{c}0.74 \\
\pm 0.43 \\
0.04\end{array}$ & 0.75 & $\begin{array}{c}0.70 \\
\pm 0.46 \\
0.07\end{array}$ & $\begin{array}{c}0.76 \\
\pm 0.50 \\
0.05\end{array}$ & $\begin{array}{c}0.73 \\
\pm 0.50 \\
0.04\end{array}$ & $2.60 *$ & $2.10 *$ \\
\hline $\begin{array}{c}\text { Encouragement } \\
\text { of Social } \\
\text { Maturity }\end{array}$ & $\begin{array}{c}3.11 \\
\pm 0.95 \\
0.62\end{array}$ & $\begin{array}{c}2.73 \\
\pm 0.93 \\
0.54\end{array}$ & $\begin{array}{c}2.29 \\
\pm 0.93 \\
0.08\end{array}$ & $1.88 *$ & $\begin{array}{c}3.18 \\
\pm 0.97 \\
0.14\end{array}$ & $\begin{array}{c}2.38 \\
\pm 1.02 \\
0.11\end{array}$ & $\begin{array}{c}2.78 \\
\pm 1.04 \\
0.09\end{array}$ & $3.14 * *$ & 1.55 \\
\hline
\end{tabular}

Table value $=1.64$; $\mathrm{df}$ for $\mathrm{AWG}=108$; $\mathrm{df}$ for $\mathrm{HBG}=124$; parenthesis indicating Standard Error $(\mathrm{SE})$

*significant difference at $0.05 ; * *$ significant difference at 0.01 
Table.3 Mean score distribution on encouragement of social maturity of sample children (4-5 years)

\begin{tabular}{|c|c|c|c|c|c|c|c|c|c|}
\hline \multirow[t]{2}{*}{ Indicators } & \multicolumn{4}{|c|}{ AWG $(n=200)$} & \multicolumn{4}{|c|}{ HBG $(n=200)$} & \multirow{2}{*}{$\begin{array}{c}\begin{array}{c}\text { Overall } \\
\text { t-value } \\
(3 \& 6)\end{array} \\
\text { AWG\& HBG }\end{array}$} \\
\hline & $\begin{array}{c}\text { Male (1) } \\
(n=35)\end{array}$ & $\begin{array}{c}\text { Female } \\
(2) \\
(n=8)\end{array}$ & $\begin{array}{c}\text { Total (3) } \\
(n=43)\end{array}$ & $\begin{array}{c}\text { t (1\&2) } \\
\text { AWG } \\
(\mathrm{M}-\mathrm{F})\end{array}$ & $\begin{array}{c}\text { Male (4) } \\
(n=11)\end{array}$ & $\begin{array}{c}\text { Female (5) } \\
\qquad(n=36)\end{array}$ & $\begin{array}{c}\text { Total (6) } \\
(n=47)\end{array}$ & $\begin{array}{c}\mathrm{t}(4 \& 5) \\
\text { HB } \\
(\mathrm{M}-\mathrm{F})\end{array}$ & \\
\hline $\begin{array}{l}\text { Mother asks } \\
\text { child to do } \\
\text { house work }\end{array}$ & $\begin{array}{c}0.87 \\
\pm 0.35 \\
(0.04)\end{array}$ & $\begin{array}{c}0.91 \\
\pm 0.28 \\
(0.12)\end{array}$ & $\begin{array}{c}0.89 \\
\pm 0.29 \\
(0.04)\end{array}$ & 0.33 & $\begin{array}{c}0.61 \\
\pm 0.40 \\
(0.12)\end{array}$ & $\begin{array}{c}0.82 \\
\pm 0.40 \\
(0.08)\end{array}$ & $\begin{array}{c}0.71 \\
\pm 0.47 \\
(0.07)\end{array}$ & $2.26^{*}$ & $2.92 *$ \\
\hline $\begin{array}{l}\text { Mother asks } \\
\text { child to take } \\
\text { care of siblings }\end{array}$ & $\begin{array}{c}0.25 \\
\pm 0.20 \\
(0.08)\end{array}$ & $\begin{array}{c}0.51 \\
\pm 0.46 \\
(0.16)\end{array}$ & $\begin{array}{c}0.38 \\
\pm 0.20 \\
(0.07)\end{array}$ & $2.34^{*}$ & $\begin{array}{c}0.27 \\
\pm 0.18 \\
(0.14)\end{array}$ & $\begin{array}{c}0.42 \\
\pm 0.50 \\
(0.08)\end{array}$ & $\begin{array}{c}0.34 \\
\pm 0.49 \\
(0.07)\end{array}$ & $2.84^{*}$ & 0.78 \\
\hline $\begin{array}{l}\text { During eating } \\
\text { times a family } \\
\text { members is with } \\
\text { child }\end{array}$ & $\begin{array}{c}0.75 \\
\pm 0.49 \\
(0.08)\end{array}$ & $\begin{array}{c}0.40 \\
\pm 0.26 \\
(0.16)\end{array}$ & $\begin{array}{c}0.57 \\
\pm 0.50 \\
(0.07)\end{array}$ & $2.81 *$ & $\begin{array}{c}0.36 \\
\pm 0.20 \\
(0.15)\end{array}$ & $\begin{array}{c}0.36 \\
\pm 0.48 \\
(0.08)\end{array}$ & $\begin{array}{c}0.36 \\
\pm 0.48 \\
(0.07)\end{array}$ & 0.01 & $1.99 *$ \\
\hline $\begin{array}{l}\text { Mother greets } \\
\text { the child }\end{array}$ & $\begin{array}{l}0.62 \\
\pm 0.45 \\
(0.07)\end{array}$ & $\begin{array}{c}0.28 \\
\pm 0.11 \\
(0.18)\end{array}$ & $\begin{array}{c}0.46 \\
\pm 0.40 \\
(0.07)\end{array}$ & $3.84 *$ & $\begin{array}{c}0.70 \\
\pm 0.46 \\
(0.14)\end{array}$ & $\begin{array}{c}0.31 \\
\pm 0.46 \\
(0.07)\end{array}$ & $\begin{array}{c}0.52 \\
\pm 0.49 \\
(0.07)\end{array}$ & $2.62 *$ & 0.53 \\
\hline $\begin{array}{l}\text { Mother } \\
\text { promotes } \\
\text { cooperation, } \\
\text { sharing and } \\
\text { helping }\end{array}$ & $\begin{array}{l}0.62 \\
\pm 0.45 \\
(0.07)\end{array}$ & $\begin{array}{c}0.71 \\
\pm 0.51 \\
(0.18)\end{array}$ & $\begin{array}{c}0.67 \\
\pm 0.46 \\
(0.07)\end{array}$ & 0.48 & $\begin{array}{c}0.55 \\
\pm 0.52 \\
(0.15)\end{array}$ & $\begin{array}{c}0.42 \\
\pm 0.50 \\
(0.08)\end{array}$ & $\begin{array}{c}0.48 \\
\pm 0.50 \\
(0.07)\end{array}$ & $1.74 *$ & $2.45 *$ \\
\hline $\begin{array}{l}\text { Encouragement } \\
\text { of Social } \\
\text { Maturity }\end{array}$ & $\begin{array}{r}2.82 \\
\pm 0.89 \\
(0.15)\end{array}$ & $\begin{array}{c}3.14 \\
\pm 1.12 \\
(0.39)\end{array}$ & $\begin{array}{c}2.99 \\
\pm 0.93 \\
(0.14)\end{array}$ & 0.99 & $\begin{array}{c}2.52 \\
\pm 1.34 \\
(0.40)\end{array}$ & $\begin{array}{c}2.33 \\
\pm 1.09 \\
(0.18) \\
\end{array}$ & $\begin{array}{c}2.41 \\
\pm 1.17 \\
(0.17)\end{array}$ & 1.31 & $2.88^{*}$ \\
\hline
\end{tabular}

Table value $=1.64$; $\mathrm{df}$ for $\mathrm{AWG}=108$; $\mathrm{df}$ for $\mathrm{HBG}=124$; parenthesis indicating Standard Error $(\mathrm{SE})$

*significant difference at 0.05 ;

Table.4 Mean score distribution on encouragement of social maturity of sample children (5-6 years)

\begin{tabular}{|c|c|c|c|c|c|c|c|c|c|}
\hline \multirow[t]{2}{*}{ Indicators } & \multicolumn{4}{|c|}{ AWG $(n=200)$} & \multicolumn{4}{|c|}{ HBG $(n=200)$} & \multirow{2}{*}{$\begin{array}{c}\text { Overal } \\
\text { t-value } \\
(3 \& 6)\end{array}$} \\
\hline & $\begin{array}{c}\text { Male } \\
(1) \\
(n=25)\end{array}$ & $\begin{array}{c}\text { Female } \\
\qquad \begin{array}{c}(2) \\
(n=22)\end{array}\end{array}$ & $\begin{array}{c}\text { Total } \\
(3) \\
(n=47)\end{array}$ & $\begin{array}{c}t \\
(1 \& 2)\end{array}$ & $\begin{array}{c}\text { Male (4) } \\
(n=3)\end{array}$ & $\begin{array}{c}\text { Female } \\
(5) \\
(n=24)\end{array}$ & $\begin{array}{c}\text { Total } \\
(6) \\
(\mathbf{n}=27)\end{array}$ & $\begin{array}{c}t \\
(4 \& 5)\end{array}$ & \\
\hline $\begin{array}{l}\text { Mother asks child to } \\
\text { do house work }\end{array}$ & $\begin{array}{c}0.82 \\
\pm 0.36 \\
(0.12)\end{array}$ & $\begin{array}{c}0.94 \\
\pm 0.39 \\
(0.08)\end{array}$ & $\begin{array}{c}0.91 \\
\pm 0.28 \\
(0.04)\end{array}$ & $2.30 *$ & $\begin{array}{c}0.71 \\
\pm 0.22 \\
(0.10)\end{array}$ & $\begin{array}{c}0.98 \\
\pm 0.46 \\
(0.09)\end{array}$ & $\begin{array}{c}0.85 \\
\pm 0.44 \\
(0.08)\end{array}$ & $2.06^{*}$ & 1.05 \\
\hline $\begin{array}{l}\text { Mother asks child to } \\
\text { take care of siblings }\end{array}$ & $\begin{array}{c}0.60 \\
\pm 0.50 \\
(0.10)\end{array}$ & $\begin{array}{c}0.68 \\
\pm 0.47 \\
(0.10)\end{array}$ & $\begin{array}{c}0.64 \\
\pm 0.48 \\
(0.07)\end{array}$ & 0.57 & $\begin{array}{c}0.46 \\
\pm 0.37 \\
(0.33)\end{array}$ & $\begin{array}{l}0.67 \\
\pm 0.50 \\
(0.10)\end{array}$ & $\begin{array}{c}0.56 \\
\pm 0.50 \\
(0.09)\end{array}$ & $2.31^{*}$ & 0.66 \\
\hline $\begin{array}{l}\text { During eating times } \\
\text { a family members is } \\
\text { with child }\end{array}$ & $\begin{array}{c}0.60 \\
\pm 0.50 \\
(0.10)\end{array}$ & $\begin{array}{l}0.55 \\
\pm 0.51 \\
(0.09)\end{array}$ & $\begin{array}{c}0.57 \\
\pm 0.50 \\
(0.07)\end{array}$ & 0.37 & $\begin{array}{c}0.99 \\
\pm 0.48 \\
(0.09)\end{array}$ & $\begin{array}{c}0.58 \\
\pm 0.50 \\
(0.10)\end{array}$ & $\begin{array}{c}0.79 \\
\pm 0.49 \\
(0.09)\end{array}$ & $2.40^{*}$ & $2.46 *$ \\
\hline $\begin{array}{l}\text { Mother greats to } \\
\text { child }\end{array}$ & $\begin{array}{l}0.55 \\
\pm 0.47 \\
(0.15)\end{array}$ & $\begin{array}{c}0.32 \\
\pm 0.11 \\
(0.10)\end{array}$ & $\begin{array}{c}0.43 \\
\pm 0.30 \\
(0.07)\end{array}$ & $2.56^{*}$ & $\begin{array}{c}0.67 \\
\pm 0.57 \\
(0.33)\end{array}$ & $\begin{array}{c}0.58 \\
\pm 0.50 \\
(0.10)\end{array}$ & $\begin{array}{c}0.62 \\
\pm 0.50 \\
(0.09)\end{array}$ & $1.99 *$ & $2.38 *$ \\
\hline $\begin{array}{l}\text { Mother promotes } \\
\text { cooperation, sharing } \\
\text { and helping }\end{array}$ & $\begin{array}{c}0.48 \\
\pm 0.31 \\
(0.10)\end{array}$ & $\begin{array}{c}0.64 \\
\pm 0.49 \\
(0.10)\end{array}$ & $\begin{array}{c}0.56 \\
\pm 0.50 \\
(0.07)\end{array}$ & $2.06 *$ & $\begin{array}{c}0.90 \\
\pm 0.45 \\
(0.00)\end{array}$ & $\begin{array}{c}0.63 \\
\pm 0.49 \\
(0.10)\end{array}$ & $\begin{array}{c}0.81 \\
\pm 0.48 \\
(0.09)\end{array}$ & $2.29 *$ & $2.95 *$ \\
\hline $\begin{array}{l}\text { Encouragement } \\
\text { of Social } \\
\text { Maturity }\end{array}$ & $\begin{array}{c}3.23 \\
\pm 0.81 \\
(0.16)\end{array}$ & $\begin{array}{c}\mathbf{3 . 0 0} \\
\mathbf{\pm 0 . 9 7} \\
(\mathbf{0 . 2 0})\end{array}$ & $\begin{array}{c}3.11 \\
\pm 0.89 \\
(0.13)\end{array}$ & 0.98 & $\begin{array}{c}3.08 \\
\pm 0.00 \\
(\mathbf{0 . 0 0})\end{array}$ & $\begin{array}{c}2.16 \\
\pm 0.97 \\
(0.20)\end{array}$ & $\begin{array}{c}2.62 \\
\pm 0.97 \\
(0.18)\end{array}$ & $2.69 *$ & $2.60 *$ \\
\hline
\end{tabular}

Table value=1.64; df for $\mathrm{AWG}=108$; $\mathrm{df}$ for $\mathrm{HBG}=124$; parenthesis indicating Standard Error $(\mathrm{SE})$

*significant difference at 0.05 
Similarly, mothers were found to be greeting more male children in both the groups.

Overall, significant difference was seen in AWG and HBG among children aged 4-5 years in respect of asking children to do household work and promoting cooperation and other pro-social qualities and family members seen with child during meals $(\mathrm{t}=$ 1.99). More of the home based mothers were found to be encouraging social maturity among their children.

\section{Encouragement of social maturity (5-6 years)}

The data in table 4 reveals that among home based group, significant gender difference was observed on all the dimensions of encouragement of social maturity. Mothers of male children greeted them more in anganwadi group $(\mathrm{t}=2.56)$, promoting cooperation, sharing $(t=2.06)$ and more females received stimulation in respect to social maturity from mothers in asking them to do house related activities (2.30) such as cooking, sweeping, cleaning, whereas mothers of boys used to ask family members to accompany the children when they were having meals. Overall significant difference was observed among AWG and HBG ( $\mathrm{t}=$ $2.60)$ in this aspect of stimulation among 5-6 year age group.

\section{Concluding remarks on encouragement of social maturity of sample children}

Encouragement makes the child confident and competent in the society. Mothers play an important role in encouraging the child on different aspects as mothers are considered to be the first whom the child feels, observes and learns with, she can inculcate good skills among children through their encouraging, positive and good behaviour. Though this is missing in poverty settings but still their mothers try to provide opportunities as much they know and can do. The difference on encouragement of social maturity was seen among children 4-5 years and 5-6 years of age where HBG received more encouragement from their mothers in respect of asking to do household work, cooperation and pro-social qualities. Age trend on this indicator also showed significant difference on all the aspects of encouragement of social maturity except promoting pro-social qualities in AWG and asking child to take care of siblings among HBG.

The present research data revealed significant differences in respect of stimulation provided by mothers for encouraging development of social maturity in children among selected poverty setting. This study dispels the notion that maternal stimulation is low in poverty settings and it was seen that females were given more responsibility as compared to males. Differences were also seen with respect to children belonging to $\mathrm{AW} / \mathrm{HB}$ groups. This study has implications for professionals, researchers and programme planners aiming to improve the quality of stimulation and development of young children in economically disadvantaged section of society.

\section{References}

Brotherson, S. (2006). Keys to assisting social development among young children. Department of Agriculture cooperating. North Dakota State University, U.S.A.

http://www.beadforlife.org http://www.globalfundforchildren.org http://www.techxlab.org

Manocha, A. (2010). Maternal Stimulation Level of Intervention. Studies of Home and Community Science, 2(2), 87-92.

Manocha, A., and Balda, S. (2011). Concept development status of rural preschoolers. Journal of Human 
Ecology, 16(2), 113-118.

Pooja (2007). Effect of familial factors on children's intelligence. Indian
Psychological Review, 56(1), 8-11. wcd.nic.in/icds/icds.aspx Www.jstor.org

\section{How to cite this article:}

Anupa Sharma, Sabiya Asmat and Tashi Dolkar. 2019. Role of Mother and Social Maturity among Children in Poverty Setting. Int.J.Curr.Microbiol.App.Sci. 8(08): 155-161.

doi: https://doi.org/10.20546/ijcmas.2019.808.019 